\title{
Antioxidant activity of fermented green coffee beans
}

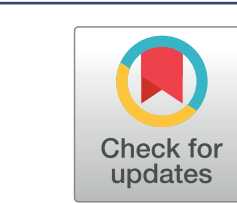

\author{
Jesslyn Jelena $\mathbb{D}$, Putu Sanna Yustiantara $\mathbb{D}^{*}$ \\ Department of Pharmacy, Faculty of Mathematics and Natural Science, Udayana University, Bukit Jimbaran, Badung, Bali 80361, \\ Indonesia \\ *Corresponding author: J. Kampus Bukit Jimbaran, Badung, Bali 80361, Indonesia. Email: putuyustiantara@unud.ac.id
}

\begin{abstract}
A green coffee bean contains phenolic compounds with strong antioxidant activity, such as chlorogenic acid. Fermentation is one of the ways to increase the antioxidant activity of coffee beans by using microorganisms. This review aims to study the antioxidant activity of fermented green coffee beans and the factors involved in the fermentation process. We selected original research articles providing data on the antioxidant activity of fermented green coffee beans published from 2015 to 2021. Fermented green coffee beans shows stronger antioxidant activity compared to the controls. The amount of substrate, yeast (as a starter), and fermentation time influence the antioxidant activity of the fermented green coffee beans. The fermented green coffee beans with yeast had significantly higher antioxidant activity than those in unfermented coffee.
\end{abstract}

Keywords: fermentation, green coffee bean, chlorogenic acid, antioxidant activity

\section{Introduction}

The coffee plant (Coffea sp.) is one of the commodities in Indonesia. The chemical composition of green coffee beans depends on the species, variety, environment, maturity level, and storage conditions. The major acid content in coffee beans is chlorogenic acid ( $8 \%$ in unprocessed coffee beans and $4.5 \%$ in roasted coffee) [1]. Chlorogenic acid, a phenolic compound and ester group, is formed from quinic acid and several trans-cinnamic acids, generally caffeine, p-coumaric acid, and ferulic acid (Figure 1) [2]. One of the benefits of chlorogenic acid for humans is an antioxidant [3].

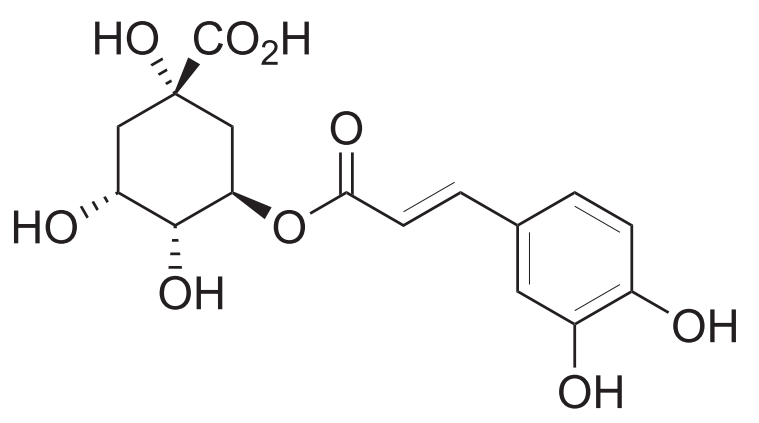

Figure 1. Chemical structure of chlorogenic acid

Some studies reported various methods to process coffee beans $[4,5]$; one method is fermentation. Some factors affect the fermentation such as type and amount of substrate, type and amount of starter, temperature, $\mathrm{pH}$, and fermentation duration [6]. Coffee bean fermentation is part of the post-harvest process, that can increase the antioxidant activity of green beans. Fermentation can increase antioxidant activity, phenolic and flavonoid content in soybeans [7], okra seeds [8], nuts [9,10], and fermented coffee [11]. However, green coffee bean fermentation has not been widely studied as a second processing step to increase the activity of antioxidants and phenolic compounds. This review article aims to analyze the antioxidant activity of fermented green coffee beans and the factors affected the fermentation process.

\section{Methods}

This review was constructed by articles published in 2015-2021 from national and international journals through scientific databases such as PubMed, Google Scholar, and Science Direct, with the keywords fermentation, green bean, antioxidants, chlorogenic acid, and optimization fermentation. The inclusion criteria are articles containing coffee fermentation with antioxidant activity, while the exclusion criteria are articles only discussing coffee fermentation without antioxidant activity. The articles were collected and combined to study the antioxidant activity of fermented green coffee beans and the factors in the fermentation process affecting the antioxidant activity. 


\section{Coffee bean fermentation process}

Fermentation can be carried out using bacteria, fungi, yeast, or a mixture of various microorganisms. The mucilage layer of coffee beans rich in sugar and pectin is a source of nutrition for the microorganism [12]. Sugar and pectin will be converted into alcohols and organic acids during fermentation, yielding lower acidity and changing the texture of the mucilage layer that is easier to wash and remove [13].

Most phenolic compounds in the green coffee bean are present as glycosides. These glycosides contain organic acids such as chlorogenic, ferulic, and caffeic acids $[14,15]$. The high molecular weight and hydrophilicity of these acid glycosides limit their bioavailability contrast to their free forms with several hydroxyl groups $[15,16]$. Fermentation using appropriate microorganisms can break the acid glycosides into their phenolic compounds and consequently their functional properties [15]. The summary of fermentation condition and the antioxidant activity is presented in Table 1 .

Table 1. Fermentation condition and the antioxidant of coffee bean

\begin{tabular}{|c|c|c|c|}
\hline Type of yeast & Fermentation condition & Results & Reference \\
\hline $\begin{array}{l}\text { Saccharomyces } \\
\text { cerevisiae }\end{array}$ & $\begin{array}{l}\text { Wet fermentation } \\
\text { Time: } 79.09,120,180,240 \text {, and } 280.90 \mathrm{~h} \\
\text { Temperature: } 25,31 \text {, and } 37^{\circ} \mathrm{C} \\
\text { Substrate: } 1 \mathrm{~kg} \\
\text { Sugar: } 3.18 \%, 10 \%, 20 \%, 30 \%, 36.81 \% \\
\text { Starter: } 0.3 \%, 1.5 \%, 3.25 \%, 5 \%, 6.19 \%\end{array}$ & $\begin{array}{l}\text { Optimum composition: } \\
\text { yeast } 3.25 \% \text {; sugar } 21.38 \% ; 124.73 \mathrm{~h} \text { of } \\
\text { fermentation time resulted in a total } \\
\text { phenol of } 10.22 \mathrm{mg} \mathrm{GAE} / \mathrm{g} \text {. }\end{array}$ & [17] \\
\hline $\begin{array}{l}\text { Wickerhamomyces } \\
\text { anomalus (strain } \\
\text { KNU18Y3) }\end{array}$ & $\begin{array}{l}\text { Time: } 0-24 \mathrm{~h} \\
\text { Temperature: } 30^{\circ} \mathrm{C} \\
\text { Substrate: } 300 \mathrm{~g} \\
\text { Starter: } 1.0 \times 10^{4} \mathrm{CFU} / \mathrm{g} \text { coffee beans }\end{array}$ & $\begin{array}{l}\text { Method: ORAC Antioxidant activity of } \\
\text { control: } 48.31 \mu \mathrm{M} \mathrm{TE} / \mathrm{mL} \\
\text { Antioxidant activity of fermented green } \\
\text { coffee bean: } 47.82 \mu \mathrm{M} \mathrm{TE} / \mathrm{mL} \\
\text { Method: SOD Antioxidant activity of } \\
\text { control: } 89.54 \% \\
\text { Antioxidant activity of fermented green } \\
\text { coffee bean: } 89.05 \%\end{array}$ & [18] \\
\hline $\begin{array}{l}\text { Acetobacter xylinum and } \\
\text { S. cerevisiae }\end{array}$ & $\begin{array}{l}\text { Wet fermentation } \\
\text { Time: } 6,12 \text {, and } 18 \text { days } \\
\text { Temperature: } 25,31 \text {, dan } 37^{\circ} \mathrm{C} \\
\text { Substrate: } 0.375 \mathrm{~g} \\
\text { Sugar: } 5 ; 7.5 ; \text { dan } 10 \%(\mathrm{w} / \mathrm{v}) \\
\text { Starter: } 20 \mathrm{~g}\left(1.0 \times 10^{8} \mathrm{CFU} / \mathrm{mL}\right)\end{array}$ & $\begin{array}{l}\text { Optimum composition: sugar } 6.77 \% \text {, } \\
\text { temperature } 25^{\circ} \mathrm{C} \text {, and } 18 \text { days of } \\
\text { fermentation resulted in } 138.78 \% \\
\text { chlorogenic acid. }\end{array}$ & [19] \\
\hline $\begin{array}{l}\text { S. cerevisiae (strain } \\
\text { KNU18Y13), } \\
\text { Saccharomycopsis } \\
\text { fibuligera (strain } \\
\text { KNU18Y4), and } \\
\text { S. cerevisiae (strain } \\
\text { KNU18Y12) }\end{array}$ & $\begin{array}{l}\text { Time: } 0-48 \mathrm{~h} \\
\text { Temperature: } 30^{\circ} \mathrm{C} \\
\text { Substrate: } 250 \mathrm{~g} \\
\text { Starter: } 1.0 \times 10^{4} \mathrm{CFU} / \mathrm{g} \text { coffee beans }\end{array}$ & $\begin{array}{l}\text { Method: ORAC } \\
\text { Antioxidant activity of control: } 30.37 \\
\mu \mathrm{M} T \mathrm{TE} / \mathrm{mL} \\
\text { Antioxidant activity of fermented green } \\
\text { coffee bean using KNU18Y13 yeast } \\
\text { strain: } 42.42 \mu \mathrm{M} \mathrm{TE} / \mathrm{mL} \\
\text { Antioxidant activity of fermented green } \\
\text { coffee bean using KNU18Y4 yeast } \\
\text { strain: } 42.09 \mu \mathrm{M} \mathrm{TE} / \mathrm{mL} \\
\text { Antioxidant activity of fermented green } \\
\text { coffee bean using KNU18Y12 yeast } \\
\text { strain: } 48.83 \mu \mathrm{M} \text { TE/mL } \\
\text { Method: SOD } \\
\text { Antioxidant activity of control: } 70.23 \% \\
\text { Antioxidant activity of fermented green } \\
\text { coffee bean using KNU18Y13 yeast } \\
\text { strain: } 82.12 \% \\
\text { Antioxidant activity of fermented green } \\
\text { coffee bean using KNU18Y4 yeast } \\
\text { strain: } 82.15 \% \\
\text { Antioxidant activity of fermented green } \\
\text { coffee bean using KNU18Y12 yeast } \\
\text { strain: } 88.62 \%\end{array}$ & {$[20]$} \\
\hline
\end{tabular}




\begin{tabular}{|c|c|c|c|}
\hline Type of yeast & Fermentation condition & Results & Reference \\
\hline S. cerevisiae & $\begin{array}{l}\text { Solid-state fermentation } \\
\text { Time: } 24 \mathrm{~h} \\
\text { Temperature: } 28^{\circ} \mathrm{C} \\
\text { Substrate: } 400 \mathrm{~g} \\
\text { Starter: } 1.0 \times 10^{7} \mathrm{CFU} / \mathrm{g}\end{array}$ & $\begin{array}{l}\text { The final concentration of chlorogenic } \\
\text { acid is } 30 \mathrm{mg} / \mathrm{L}\end{array}$ & {$[21]$} \\
\hline $\begin{array}{l}\text { Three commercial } \\
\text { yeasts (S. cerevisiae) }\end{array}$ & $\begin{array}{l}\text { Time: } 0-24 \mathrm{~h} \\
\text { Temperature: } 30^{\circ} \mathrm{C} \\
\text { Substrate: } 300 \mathrm{~g} \\
\text { Starter: } 1.0 \times 10^{7} \mathrm{CFU} / \mathrm{mL}\end{array}$ & $\begin{array}{l}\text { Method: ORAC } \\
\text { Antioxidant activity of control: } 14.11 \\
\mu \mathrm{M} \mathrm{TE} / \mathrm{mL} \\
\text { Antioxidant activity of fermented green } \\
\text { coffee bean: } 34.95 \mu \mathrm{M} \mathrm{TE} / \mathrm{mL} ; 37.44 \mu \mathrm{M} \\
\mathrm{TE} / \mathrm{mL} ; 34.09 \mu \mathrm{M} \mathrm{TE} / \mathrm{mL} \\
\text { Method: SOD } \\
\text { Antioxidant activity of control: } 29.63 \% \\
\text { Antioxidant activity of fermented green } \\
\text { coffee bean: } 82.76 \% ; 79.79 \% ; 69.58 \%\end{array}$ & [11] \\
\hline Yeast mixtures & $\begin{array}{l}\text { Spontaneous fermentation } \\
\text { Time: } 48 \mathrm{~h} \\
\text { Substrate: } 75 \mathrm{~kg}\end{array}$ & $\begin{array}{l}\text { Yeast population increased from } 6.60 \\
\text { to } 7.89 \mathrm{log} \mathrm{CFU} / \mathrm{g}^{-1} \text {; yeast population } \\
\text { mainly represented by Saccharomyces } \\
\text { sp.; organic acids production (mainly } \\
\text { lactic ( } 3.35 \mathrm{~g} / \mathrm{L} \text { ) and acetic }(1.27 \mathrm{~g} / \mathrm{L} \text { ) } \\
\text { acids). SPME-GC-MS analysis revealed a } \\
\text { total of } 25 \text { volatile organic compounds } \\
\text { with predominance of hydrocarbons } \\
\text { ( } 9 \text { compounds) and higher alcohols ( } 6 \\
\text { compounds). }\end{array}$ & [22] \\
\hline $\begin{array}{l}\text { S. cerevisiae (Four } \\
\text { strains, coded as L1, L2, } \\
\text { L5, and L7) }\end{array}$ & $\begin{array}{l}\text { Wet fermentation } \\
\text { Time: } 12 \text { and } 36 \mathrm{~h} \\
\text { Substrate: } 50 \mathrm{~kg} \\
\text { Sugar: } 3.18 \%, 10 \%, 20 \%, 30 \% \text {, and } \\
36.81 \% \\
\text { Starter: } 1 \mathrm{~g} / \mathrm{kg} \text { of depulped coffee }\end{array}$ & $\begin{array}{l}\text { Concentration of chlorogenic acid } \\
\text { Control: } 9.66 \% \\
\text { L1 (12 h): } 10.47 \% \\
\text { L1 ( } 36 \text { h): } 10.02 \% \\
\text { L2 (12 h): } 9.88 \% \\
\text { L2 ( } 36 \text { h): } 9.55 \% \\
\text { L5 (12 h): } 9.22 \% \\
\text { L5 ( } 36 \text { h): } 9.73 \% \\
\text { L7 (12 h): } 9.33 \% \\
\text { L7 ( } 36 \text { h): } 8.74 \%\end{array}$ & [23] \\
\hline
\end{tabular}

CFU: colony forming unit; GAE: gallic acid equivalent; ORAC: oxygen radical absorbance capacity; TE: Trolox equivalent; SOD: superoxide dismutase-like activity

\section{Effect of fermentation on antioxidant activity}

The articles in Table 1 reporting antioxidant activity of fermented green coffee bean then selected and further analyzed by counting the increase of antioxidant activity compared to control and displayed in Table 2.

Haile and Kang (2019) reported the increase of antioxidant activity of fermented green coffee bean with total phenolic contents (TPC) of the extracts (1.11-1.30 GAE $\mathrm{mg} / \mathrm{mL}$ ) significantly higher than the control $(0.72 \mathrm{GAE} \mathrm{mg} / \mathrm{mL})$ [20]. The fermented green coffee bean using $S$. cerevisiae (strain KNU18Y13) and S. fibuligera (strain KNU18Y4) produced higher antioxidant activity as evaluated by ORAC and SOD methods. The ORAC quantifies the antioxidant capacity based on a probe's fluorescent signal, which is quenched in the presence of reactive oxygen species (ROS). The SOD activity uses a xanthine/xanthine oxidase (XOD) system to generate superoxide anions and a chromagen to produce a water-soluble formazan dye upon reduction by superoxide anions. The SOD activity is determined as the inhibition or reduction of chromagen. The antioxidant activity of fermented green coffee bean with W. anomalus (KNU18Y3 strain) was not significantly different from the control, while the TPC of the control was $0.70 \mathrm{GAE} \mathrm{mg} / \mathrm{mL}$ and of the fermented green coffee bean was $0.91 \mathrm{GAE} \mathrm{mg} /$ $\mathrm{mL}$ [18].

In the wet processing method, $W$. anomalus and $S$. cerevisiae can produce a pectinase enzyme, so they are selected as a starter culture for coffee bean fermentation. However, S. cerevisiae has a higher ethanol tolerance and 
Table 2. Antioxidant activity of fermented green coffee bean

\begin{tabular}{|c|c|c|c|c|}
\hline $\begin{array}{l}\text { Antioxidant } \\
\text { activity method }\end{array}$ & $\begin{array}{c}\text { Antioxidant activity of } \\
\text { fermented green bean coffee }\end{array}$ & $\begin{array}{l}\text { Antioxidant } \\
\text { activity of control }\end{array}$ & $\begin{array}{l}\text { The increase amount of } \\
\text { antioxidant activity }\end{array}$ & Reference \\
\hline \multirow[t]{3}{*}{ ORAC } & $42.42 \mu \mathrm{M} \mathrm{TE} / \mathrm{mL}$ & & $12.05 \mu \mathrm{M} \mathrm{TE} / \mathrm{mL}$ & \multirow{6}{*}[20]{} \\
\hline & $42.09 \mu \mathrm{M} \mathrm{TE} / \mathrm{mL}$ & $30.37 \mu \mathrm{M} \mathrm{TE} / \mathrm{mL}$ & $11.72 \mu \mathrm{M} \mathrm{TE} / \mathrm{mL}$ & \\
\hline & $48.83 \mu \mathrm{M}$ TE/mL & & $18.46 \mu \mathrm{M}$ TE/mL & \\
\hline \multirow[t]{3}{*}{ SOD } & $82.12 \%$ & & $11.89 \%$ & \\
\hline & $82.15 \%$ & $70.23 \%$ & $11.92 \%$ & \\
\hline & $88.62 \%$ & & $18.39 \%$ & \\
\hline \multirow[t]{3}{*}{ ORAC } & $34.95 \mu \mathrm{M} \mathrm{TE} / \mathrm{mL}$ & & $20.84 \mu \mathrm{M} \mathrm{TE} / \mathrm{mL}$ & \multirow{6}{*}{ [11] } \\
\hline & $37.44 \mu \mathrm{M} \mathrm{TE} / \mathrm{mL}$ & $14.11 \mu \mathrm{M} \mathrm{TE} / \mathrm{mL}$ & $23.33 \mu \mathrm{M} \mathrm{TE} / \mathrm{mL}$ & \\
\hline & $34.09 \mu \mathrm{M}$ TE/mL & & $19.98 \mu \mathrm{M}$ TE/mL & \\
\hline \multirow[t]{3}{*}{ SOD } & $82.76 \%$ & & $53.13 \%$ & \\
\hline & $79.79 \%$ & $29.63 \%$ & $50.16 \%$ & \\
\hline & $69.58 \%$ & & $39.95 \%$ & \\
\hline ORAC & $47.82 \mu \mathrm{M} \mathrm{TE} / \mathrm{mL}$ & $48.31 \mu \mathrm{M} \mathrm{TE} / \mathrm{mL}$ & - $0.49 \mu \mathrm{M} \mathrm{TE} / \mathrm{mL}$ & \multirow{2}{*}[18]{} \\
\hline SOD & $89.05 \%$ & $89.54 \%$ & $-0.49 \%$ & \\
\hline
\end{tabular}

maintains fermentation activity than $W$. anomalus [24]. Therefore, the type of yeast for the fermentation process significantly affects the yield of secondary metabolites and the antioxidant activity of the fermented green coffee bean. The fermentation time of green coffee beans disturbs the antioxidant activity. A similar profile was also noted for the amount of starter used in the fermentation process.

Green coffee beans contain phenolic compounds involved in the scavenging activity of ROS. Chlorogenic acid is the main phenolic component of green coffee beans, which exhibit antimutagenic, anticarcinogenic, antibacterial, and antioxidant activities [25]. Besides, green coffee bean phytochemicals reduce visceral fat and have been added to skin cosmetics to prevent skin aging [26].

\section{Conclusion and future direction}

The fermentation process can increase the antioxidant activity of green coffee beans. The antioxidant activity was affected by the amount of starter, fermentation time, and the amount of substrate. Optimizing fermentation conditions for producing optimal antioxidant activity is needed to utilize and develop fermented green coffee beans.

\section{Declaration of interest}

None.

\section{Author contributions}

JJ, PSY conceptualized the review article and search literature for the data, JJ wrote the original draft, JJ reviewed and edited the final version, PSY supervised the review process.

Received: 18 December 2021

Accepted: 3 January 2022

Published online: 18 January 2022

\section{References}

1. Yusianto Y, Nugroho D. Physical and flavor profiles of arabica coffee as affected by cherry storage before pulping. PP. 2014;30: 137-158. https://doi.org/10.22302/iccri.jur. pelitaperkebunan.v30i2.7

2. Ayelign A, Sabally K. Determination of Chlorogenic Acids (CGA) in Coffee Beans using HPLC. American Journal of Research Communication. 2013;1: 78-91.

3. Husniati H, Sari MY, Sari A. Kajian: Katakterisasi senyawa aktif dalam kopi robusta sebagai antioksidan. TEGI. 2021;12: 34. https://doi.org/10.46559/tegi.v12i2.6750

4. Selmar D, Bytof G, Knopp SE, Breitenstein B. Germination of coffee seeds and its significance for coffee 
quality. Plant Biol (Stuttg). 2006;8: 260-264. https://doi. org/10.1055/s-2006-923845

5. Leloup V, Gancel C, Liardon R, Rytz A, Pithon A. Impact of wet and dry process on green coffee composition and sensory characteristics. ASIC 2004 20th International Conference on Coffee Science, Bangalore, India, 11-15 October 2004. 2005;

6. Sharma R, Garg P, Kumar P, Bhatia SK, Kulshrestha S. Microbial fermentation and its role in quality improvement of fermented foods. Fermentation. 2020;6: 106. https://doi. org/10.3390/fermentation6040106

7. Amadou I, Yong-Hui S, Sun J, Guo-Wei L. Fermented Soybean Products: Some Methods, Antioxidants Compound Extraction and their Scavenging Activity. Asian J of Biochemistry. 2009;4: 68-76. https://doi. org/10.3923/ajb.2009.68.76

8. Adetuyi FO, Ibrahim TA. Effect of Fermentation Time on the Phenolic, Flavonoid and Vitamin C Contents and Antioxidant Activities of Okra (Abelmoschus esculentus) Seeds. Nigerian Food Journal. 2014;32: 128-137. https:// doi.org/10.1016/S0189-7241(15)30128-4

9. Moktan B, Saha J, Sarkar PK. Antioxidant activities of soybean as affected by Bacillus-fermentation to kinema. Food Res Int. 2008;41: 586-593. https://doi.org/10.1016/j. foodres.2008.04.003

10. Dajanta K, Janpum P, Leksing W. Antioxidant capacities, total phenolics and flavonoids in black and yellow soybeans fermented by Bacillus subtilis: A comparative study of Thai fermented soybeans (thua nao). International Food Research Journal. 2013;20: 3125-3132.

11. Kwak HS, Jeong Y, Kim M. Effect of yeast fermentation of green coffee beans on antioxidant activity and consumer acceptability. J Food Qual. 2018;2018: 1-8. https://doi. org/10.1155/2018/5967130

12. Murthy PS, Naidu MM. Improvement of Robusta Coffee Fermentation with Microbial Enzymes. European Journal of Applied Sciences. 2011;3: 130-139.

13. Correa EC, Jiménez-Ariza T, Díaz-Barcos V, Barreiro P, Diezma B, Oteros R, et al. Advanced Characterisation of a Coffee Fermenting Tank by Multi-distributed Wireless Sensors: Spatial Interpolation and Phase Space Graphs. Food Bioprocess Technol. 2014;7: 3166-3174. https://doi. org/10.1007/s11947-014-1328-4

14. Asther M, Haon M, Roussos S, Record E, Delattre M, Lesage-Meessen L, et al. Feruloyl esterase from Aspergillus niger. Process Biochemistry. 2002;38: 685-691. https://doi. org/10.1016/S0032-9592(02)00196-6

15. Ferreira LR, Macedo JA, Ribeiro ML, Macedo GA. Improving the chemopreventive potential of orange juice by enzymatic biotransformation. Food Res Int. 2013;51: 526-535. https://doi.org/10.1016/j.foodres.2013.01.018
16. Gómez-Ruiz JA, Leake DS, Ames JM. In vitro antioxidant activity of coffee compounds and their metabolites. J Agric Food Chem. 2007;55: 6962-6969. https://doi.org/10.1021/ jf0710985

17. Maskum A, Wijonarko G, Purbowati IS mulyo, Anggriawan R. Optimization of phenolic compounds in robusta green beans coffee through the wet fermentation process with the response surface methodology. AGROINTEK: Jurnal Teknologi Industri Pertanian. 2021;15: 825-832. https:// doi.org/10.21107/agrointek.v15i3.10585

18. Haile M, Kang WH. Antioxidant Properties of Fermented Green Coffee Beans with Wickerhamomyces anomalus (Strain KNU18Y3). Fermentation. 2020;6: 18. https://doi. org/10.3390/fermentation6010018

19. Narko T, Singgih Wibowo M, Damayanti S, Wibowo I, Arbi Hadiyat M. Optimization of robusta green coffee fermentation using response surface methodology. CS. 2020;15: 1-9. https://doi.org/10.25186/.v15i.1671

20. Haile M, Kang W. Antioxidant Activity, Total Polyphenol, Flavonoid and Tannin Contents of Fermented Green Coffee Beans with Selected Yeasts. Fermentation. 2019;5: 29. https://doi.org/10.3390/fermentation5010029

21. Santos da Silveira J, Durand N, Lacour S, Belleville M-P, Perez A, Loiseau G, et al. Solid-state fermentation as a sustainable method for coffee pulp treatment and production of an extract rich in chlorogenic acids. Food and Bioproducts Processing. 2019;115: 175-184. https:// doi.org/10.1016/j.fbp.2019.04.001

22. de Carvalho Neto D, de Melo Pereira G, Tanobe V, Thomaz Soccol V, G. da Silva B, Rodrigues C, et al. Yeast Diversity and Physicochemical Characteristics Associated with Coffee Bean Fermentation from the Brazilian Cerrado Mineiro Region. Fermentation. 2017;3: 11. https://doi.org/10.3390/fermentation3010011

23. Berthiot L, Noel D, Meile JC, Sieczkowski N, Ortiz-Julien A. Effects of selected Saccharomyces cerevisiae yeast inoculation on coffee fermentation and quality. Conference: International Congress on Cocoa Coffee and Tea. 2015;

24. Ye M, Yue T, Yuan Y. Effects of sequential mixed cultures of Wickerhamomyces anomalus and Saccharomyces cerevisiae on apple cider fermentation. FEMS Yeast Res. 2014;14: 873882. https://doi.org/10.1111/1567-1364.12175

25. Dziki D, Gawlik-Dziki U, Pecio Ł, Różyło R, Świeca M, Krzykowski A, et al. Ground green coffee beans as a functional food supplement - Preliminary study. LWT Food Science and Technology. 2015;63: 691-699. https:// doi.org/10.1016/j.lwt.2015.03.076

26. Flanagan J, Bily A, Rolland Y, Roller M. Lipolytic activity of Svetol $^{\circ}$, a decaffeinated green coffee bean extract. Phytother Res. 2014;28: 946-948. https://doi.org/10.1002/ ptr.5085 